\title{
Polyol Dehydrogenases
}

\section{THE POLYOL DEHYDROGENASES OF ACETOBACTER SUBOXYDANS AND CANDIDA UTILIS*}

\author{
By A. C. ARCUSt AND N. L. EDSON \\ Department of Biochemistry, Medical School, University of Otago, New Zealand
}

(Received 22 February 1956)

In the first communication of this series it was shown that the polyol dehydrogenase of rat liver reacts specifically with diphosphopyridine nucleotide and polyhydric alcohols (pentitols, hexitols, heptitols) which contain configuration (I) or (II) (McCorkindale \& Edson, 1954).<smiles>CC(O)C(O)[C@H](O)CO</smiles>

(I)<smiles>CC(O)C(O)[C@H](O)CO</smiles>

(II)
* Site of oxidation.

Pending critical tests of homogeneity on purified material, it has been assumed that the rat-liver preparation contains a single enzyme (L-iditol dehydrogenase) possessing a specificity rule different from the Bertrand-Hudson rule, which applies to cultures of Acetobacter.

Bertrand $(1898,1904)$ discovered the selective oxidation of polyols in proliferating cells of Acetobacter xylinum and enunciated the well-known rule that was confirmed and extended by later workers who preferred to study Acetobacter suboxydans (Kluyver \& de Leeuw, 1924; Reichstein, 1934; Steiger \& Reichstein, 1935; Hann, Tilden \& Hudson, 1938; Fulmer \& Underkofler, 1947; Bernhauer, 1938, 1950; Stewart, Richtmyer \& Hudson, 1949, 1952; Totten \& Lardy, 1949; Bollenback \& Underkofler, 1950; Richtmyer, Stewart \& Hudson, 1950; Pratt, Richtmyer \& Hudson, 1952).

The contrast between the specificity of the ratliver enzyme and the behaviour of Acetobacter (Edson, 1953; McCorkindale \& Edson, 1954) makes it desirable to study the oxidation of polyhydric alcohols in cell-free extracts of the bacteria. This communication shows that $A$. suboxydans contains at least two polyol dehydrogenases, one of which is responsible for the reactions described by the

* Part 1: McCorkindale \& Edson (1954).

$\dagger$ Research Fund Fellow, University of New Zealand. 25
Bertrand-Hudson rule; the other exhibits activity resembling that of an extract made from Candida utilis.

\section{MATERIALS AND METHODS}

Organisms. Acetobacter suboxydans, no. 621, was obtained from the American Type Culture Collection, Washington, D.C. It was grown at $30^{\circ}$ for 3 days in a yeast-water medium to which $0.3 \%(w / v)$ of $\mathrm{KH}_{2} \mathrm{PO}_{4}$ and $2 \%(w / v)$ of glycerol were added (pH about 5.5). The cultures (100 ml. of medium in $500 \mathrm{ml}$. conical flasks) were aerated by continuous shaking. Yeast water was prepared by boiling $1 \mathrm{lb}$. of baker's compressed yeast with $400 \mathrm{ml}$. of water for $30 \mathrm{~min}$., allowing the yeast to settle overnight, filtering the supernatant through kieselguhr and making the volume up to $5 \mathrm{l}$. with water.

Candida utilis (strain Y 90/77) was obtained through the courtesy of the Northern Regional Research Laboratories, Department of Agriculture, U.S.A. The stock culture was maintained on malt-agar slopes. For experiments the organism was transferred either to the glucose-containing basal medium of Schultz \& Atkin (1947) or to a medium having the following composition: $2.0 \mathrm{~g}$. of $\mathrm{KH}_{2} \mathrm{PO}_{4}, 0.25 \mathrm{~g}$. of anhydrous $\mathrm{CaCl}_{2}, 0.5 \mathrm{~g}$. of $\mathrm{MgSO}_{4}, 7 \mathrm{H}_{2} \mathrm{O}, 4.5 \mathrm{~g}$. of $\left(\mathrm{NH}_{4}\right)_{2} \mathrm{SO}_{4}, 20 \mathrm{~g}$. of mannitol and tap water to 11 . The cultures were incubated at $30^{\circ}$ for 2 days and continuously shaken.

Cell-free extracts. The cells of $A$. suboxydans were harvested and washed three times with water by centrifuging. Washed cells (5-10 g.) were suspended in sufficient 0.01 M- $\mathrm{Na}_{2} \mathrm{HPO}_{4}$ solution to make a total volume of $25 \mathrm{ml}$., and disrupted by treating for $40 \mathrm{~min}$. in a Raytheon 9 kcyc./sec. sonic disintegrator. The cup assembly of the apparatus was set up in a cold room at $2-3^{\circ}$ and the internal temperature of the cup kept at $0-1^{\circ}$ by circulation of ice-water ( 1.81 ./min.). The extract was clarified by centrifuging at $20000 \mathrm{~g}$ for $30 \mathrm{~min}$. in a centrifuge operating at $-5^{\circ}$, and dialysed against water for $12 \mathrm{hr}$. at $2^{\circ}$. The extracts were clear red-brown solutions, opalescent in reflected light. Examination with a directvision spectroscope revealed cytochrome absorption bands centred approximately at 527 and $554 \mathrm{~m} \mu$., the latter band being narrower and more intense. The full enzymic activities are retained for several weeks if the extract is frozen.

The cells of $C$. utilis were harvested and washed three times with $0.9 \%(w / v) ~ N a C l$ solution. Extracts were prepared either by hand-grinding $1 \mathrm{~g}$. of wet cells and $2 \mathrm{~g}$. of powdered Pyrex glass moistened with $0.1 \mathrm{M}-\mathrm{Na}_{2} \mathrm{HPO}_{4}$ to give a thick paste and adjusting to $10 \mathrm{ml}$. with the same phosphate solution, or by autolysis of vacuum-dried cells ( $1 \mathrm{~g}$. of dry cells $/ 5 \mathrm{ml}$. of water at $38^{\circ}$ for $3 \mathrm{hr}$.). The crude extracts were clarified by centrifuging and dialysed against water for $24 \mathrm{hr}$. at $2^{\circ}$.

Bioch. 1956, 64 
Polyols and sugars. D- and L-Iditol and L-rhamnitol (gifts) were prepared by Dr D. R. D. Shaw. The sources of the other polyols and of the sugars used in this work are acknowledged in the first paper (McCorkindale \& Edson, 1954).

Coenzymes. Diphosphopyridine nucleotide (DPN) and triphosphopyridine nucleotide (TPN) were the chromatographically purified products of the Sigma Chemical Co., St Louis, U.S.A.; reduced diphosphopyridine nucleotide (DPNH) was the product of the same firm.

\section{Analytical methods}

The analytical methods were essentially the same as those used by McCorkindale \& Edson (1954). Ketoses, however, were determined by Kulka's (1956) modification of the method of Bacon \& Bell (1948) after deproteinization and, when necessary, removal of methylene blue. Fructose and sorbose were determined in mixtures by measuring the total ketose in a portion of the original solution, the fructose was destroyed by fermentation with baker's yeast $(10 \%$, $\mathrm{w} / \mathrm{v}$ ) for $4 \mathrm{hr}$. at $30^{\circ}$, the yeast was removed by centrifuging, and the residual ketose estimated. Thus the fructose was determined by difference. A water blank containing the same quantity of yeast corrected for the small amount of resorcinol-reacting material which is extracted from the yeast during the fermentation (0.16 $\mu$ mole as fructose).

\section{Preparation of phenylosazones}

The preparations were carried out as before (McCorkindale \& Edson, 1954). The phenylosazone of sorbose was amorphous when prepared by this method. It was crystallized by dissolving in water at $100^{\circ}$ and evaporating until a faint cloudiness appeared. The container was stoppered, immersed in a water bath at $100^{\circ}$ for $0.5 \mathrm{hr}$. and the bath allowed to cool slowly to room temperature.

\section{RESULTS}

\section{Oxidation of mannitol and sorbitol by extracts of Acetobacter suboxydans}

At pH 8 dialysed extracts of $A$. suboxydans reduced methylene blue anaerobically in the presence of added DPN and either mannitol or sorbitol. When methylene blue was omitted and the reactions were carried out aerobically, $\mathrm{O}_{2}$ was consumed and the products of oxidation accumulated. Mannitol gave fructose as expected, but sorbitol also formed fructose. This was surprising because $A$. suboxydans grown in yeast-water media at $\mathrm{pH} 5-6.8$ oxidizes sorbitol to sorbose in a yield greater than $90 \%$ (Fulmer \& Underkofler, 1947). At pH 5.5 the extracts did not reduce methylene blue anaerobically on addition of polyols and DPN. Aerobically with methylene blue omitted the enzyme system, like the intact bacteria, consumed $\mathrm{O}_{2}$, converting mannitol into fructose and sorbitol into sorbose.

The behaviour of the bacterial extract is explained by the experiments illustrated in Figs. 1 and 2. Oxygen consumption and simultaneous ketose formation were measured at $\mathrm{pH}$ values from $5 \cdot 6$ to
7.9. The conversion of mannitol into fructose occurs throughout this range of $\mathrm{pH}$ but the rate of oxidation exhibits a minimum about $\mathrm{pH} 6.5$. The rate of oxidation of sorbitol also passes through a minimum (pH 6.4); at $\mathrm{pH} 7 \cdot 1-7 \cdot 9$ the product is entirely fructose, whereas at pH 5.6 it is almost entirely sorbose. At intermediate $\mathrm{pH}$ values the product is a mixture of the two ketoses in proportions which depend on the $\mathrm{pH}$. At all $\mathrm{pH}$ values the $\mathrm{O}_{2}$ uptake and the ketose formation correspond to the stoicheiometry of the reaction:

$$
\text { polyol }+0 \cdot 5 \mathrm{O}_{2}=\text { ketose }+\mathrm{H}_{2} \mathrm{O} \text {. }
$$

These experiments indicated that extracts of $A$. suboxydans contain two distinct polyol dehydrogenases, one most active about pH 5.5 ('acid' enzyme) and the other about pH 8 ('alkaline'

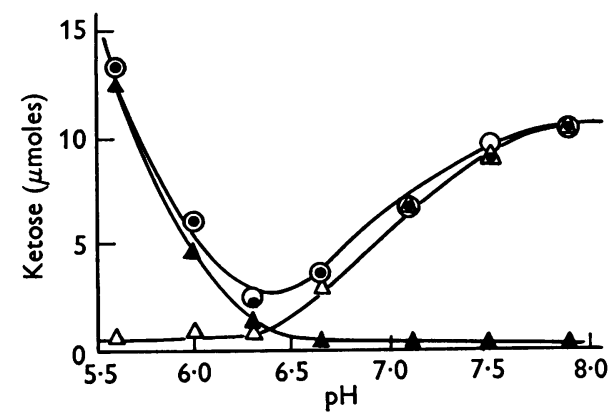

Fig. 1. Effect of $\mathrm{pH}$ on the oxidation of sorbitol in dialysed extracts of $A$. suboxydans. Each Warburg flask contained $0.5 \mathrm{ml}$. of dialysed bacterial extract, $150 \mu \mathrm{moles}$ of potassium phosphate buffer, $0.4 \mu$ mole of DPN and $150 \mu$ moles of sorbitol (added from side bulb after equilibration). Volume, $2 \cdot 7 \mathrm{ml}$. Gas, air. Temp., $25^{\circ}$. Time, $1 \mathrm{hr} . \Delta$, Fructose (analysis); $\boldsymbol{\Delta}$, sorbose (analysis); 0 , total ketose (analysis); 0 , total ketose (calculated from $\mathrm{O}_{2}$ uptake on the basis $0.5 \mu$ mole of $\mathrm{O}_{2}$ consumed $=$ $1 \cdot 0 \mu$ mole of ketose formed).

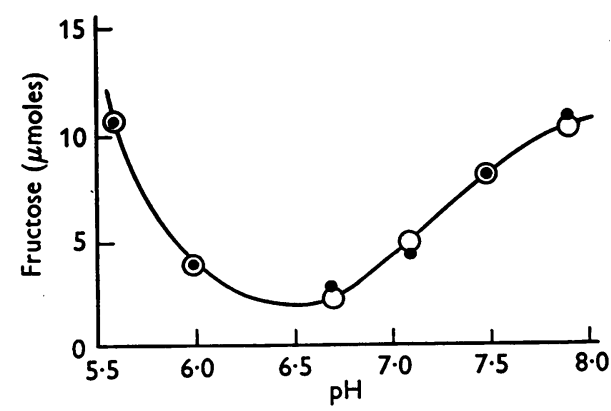

Fig. 2. Effect of $\mathrm{pH}$ on the oxidation of mannitol in dialysed extracts of $A$. suboxydans. Substrate, $150 \mu$ moles of mannitol. Conditions otherwise the same as in Fig. 1. Fructose (analysis); $O$, fructose (calculated from $\mathrm{O}_{2}$ uptake as in Fig. 1). 
enzyme). This view was confirmed by experiments (Table 1) which show that the 'alkaline' enzyme requires added DPN as a cofactor but the 'acid' enzyme does not.

\section{Partial separation of the 'acid' and 'alkaline' enzymes}

After a bacterial extract had been dialysed for 1 week and repeatedly frozen and thawed the 'acid' enzyme separated in a brown flocculent precipitate. The supernatant containing the 'alkaline' enzyme no longer took up $\mathrm{O}_{2}$ at $\mathrm{pH} 8$ in the presence of polyols and DPN unless methylene blue was added. The natural hydrogen carrier is associated with the particles containing the 'acid' enzyme. The

Table 1. Effect of DPN on the oxidation of mannitol and sorbitol by an extract of A. suboxydans

Each Warburg flask contained $0.5 \mathrm{ml}$. of dialysed bacterial extract, $15 \mu$ moles of $\mathrm{KH}_{2} \mathrm{PO}_{4}$ (to give $\mathrm{pH}$ ) or $15 \mu$ moles of $\mathrm{Na}_{2} \mathrm{HPO}_{4}$ (to give $\mathrm{pH} \mathrm{8),} 0.4 \mu$ mole of DPN where indicated, and $150 \mu$ moles of substrate (added from the side bulb after equilibration). Volume, $2.5 \mathrm{ml}$. Temp., $25^{\circ}$. Gas, air. Time, $1 \mathrm{hr}$. Inseal, $0.2 \mathrm{ml}$. of $10 \%(\mathrm{w} / \mathrm{v})$ КOH.

$\begin{array}{cccc}\text { pH } & \text { DPN } & \overbrace{\text { Mannitol }} & \begin{array}{c}\mathrm{O}_{2} \text { uptake } \\ (\mu \text { moles })\end{array} \\ 5 & \text { Absent } & 33 \cdot 6 & 38 \cdot 7 \\ 5 & \text { Present } & 32 \cdot 4 & 37 \cdot 6 \\ 8 & \text { Absent } & 0 \cdot 4 & 0 \cdot 9 \\ 8 & \text { Present } & 5 \cdot 5 & 6 \cdot 9\end{array}$

enzymes were partially separated in the following ways :

(1) An effective method, which was not available as a routine, was centrifuging of freshly prepared bacterial extract for $2 \mathrm{hr}$. in a Spinco preparative centrifuge at $60000 \mathrm{~g}$. The 'acid' enzyme was largely in the residue, which formed a red gel, and most of the 'alkaline' enzyme in the straw-coloured supernatant (Table 2).

(2) A modification of the extraction procedure gave a primary separation. The sonic disintegration was performed with the usual proportions of bacteria in $0.06 \mathrm{M}$ sodium acetate solution instead of in phosphate solution, and the extract clarified as usual. The extract was then frozen, thawed and centrifuged repeatedly until the supernatant was quite clear. The residue was suspended in $0.06 \mathrm{M}$ sodium acetate solution and washed several times with this solution. The 'acid' enzyme was in the precipitate and the 'alkaline' enzyme in the supernatant (Table 2).

(3) The two enzymes are separated less effectively by precipitation with ammonium sulphate at $0^{\circ}$. Addition of solid ammonium sulphate $(6 \cdot 25 \mathrm{~g}$.) to $25 \mathrm{ml}$. of bacterial extract freshly prepared by sonic disintegration in $0.01 \mathrm{M}-\mathrm{Na}_{2} \mathrm{HPO}_{4}$ solution gave a brown precipitate which was separated by centrifuging, dispersed in $25 \mathrm{ml}$. of water and dialysed overnight (fraction $P$ ). Ammonium sulphate $(2.5$ g.) was dissolved in the supernatant and the resulting precipitate treated in the same way (fraction $S$ ). The activities of these fractions towards mannitol (Table 2) show that the 'acid'

Table 2. Partial separation of the 'acid' and 'alkaline' enzyme present in extracts of A. suboxydans

Each Warburg flask contained 0.5-1.0 ml. of enzyme preparation, buffer solution and $150 \mu$ moles of mannitol. In the absence of substrate $\mathrm{O}_{2}$ uptake was negligible in all preparations. In the flasks containing alkaline-buffer solutions $0.4 \mu$ mole of DPN and $1.6 \mu$ moles of methylene blue were also present. In experiments with the ammonium sulphate preparation $3 \mu$ moles of $\mathrm{CaCl}_{2}$ were added. Volume, $2.8 \mathrm{ml}$. Gas, air. Temp., $25^{\circ}$. Time, $1 \mathrm{hr}$. Inseal, $0 \cdot 2 \mathrm{ml}$. of $10 \%$ (w/v) KOH.

\begin{tabular}{|c|c|c|c|}
\hline Enzyme preparation & Buffer & $\mathrm{pH}$ & $\begin{array}{l}\mathrm{O}_{2} \text { uptake } \\
\text { ( } \mathrm{moles})\end{array}$ \\
\hline \multicolumn{4}{|l|}{ Centrifuging $(60000 \mathrm{~g})$ : } \\
\hline Precipitate & Phosphate, $100 \mu$ moles & $\begin{array}{l}5 \cdot 0 \\
7 \cdot 8\end{array}$ & $\begin{array}{l}3 \cdot 3 \\
0 \cdot 8\end{array}$ \\
\hline Supernatant & & $\begin{array}{l}5 \cdot 0 \\
7 \cdot 8\end{array}$ & $\begin{array}{l}0 \cdot 3 \\
9 \cdot 3\end{array}$ \\
\hline \multicolumn{4}{|l|}{ Sodium acetate procedure: } \\
\hline Precipitate & Phosphate, $15 \mu$ moles & $\begin{array}{l}5 \cdot 6 \\
7 \cdot 5\end{array}$ & $\begin{array}{l}6 \cdot 5 \\
0 \cdot 1\end{array}$ \\
\hline Supernatant & & $\begin{array}{l}5 \cdot 6 \\
7 \cdot 5\end{array}$ & $\begin{array}{l}0 \cdot 4 \\
1 \cdot 4\end{array}$ \\
\hline \multicolumn{4}{|c|}{ Ammonium sulphate procedure: } \\
\hline Precipitate $(P)$ & Tris-succinic* acid, $1.0 \mathrm{~m}$-mole & $\begin{array}{l}4 \cdot 7 \\
7 \cdot 9\end{array}$ & $\begin{array}{l}7 \cdot 6 \\
5 \cdot 7\end{array}$ \\
\hline Supernatant $(S)$ & . & $\begin{array}{l}4 \cdot 7 \\
7 \cdot 9\end{array}$ & $\begin{array}{l}0 \cdot 3 \\
3 \cdot 8\end{array}$ \\
\hline
\end{tabular}

* This buffer was made by mixing appropriate volumes of $0 \cdot 2 \mathrm{M}$ aminotrishydroxymethylmethane (tris) solution and $0 \cdot 1$ m succinic acid solution. 
enzyme is almost entirely in fraction $P$, but two-thirds of the 'alkaline' enzyme remains in fraction $P$.

\section{Properties of the 'acid' enzyme}

In some experiments partially separated 'acid' enzyme was used; in others the unfractionated bacterial extract was examined at pH 5 to eliminate the activity of the 'alkaline' enzyme. The preparations always contained the red-brown pigment showing cytochrome absorption bands.

Solubility. Although the subcellular particles containing the 'acid' enzyme are well dispersed by sonic treatment, they are flocculated by the operations described in the preceding section. Since they are aggregated at $\mathrm{pH} 5-6$ the properties of the enzyme were studied in a suspension of extremely fine particles which do not sediment at centrifugal speeds up to $4000 \mathrm{rev} . / \mathrm{min}$. for $30 \mathrm{~min}$. They are redispersed in solutions at $\mathrm{pH} 8$. Dispersion with commercial detergents and sodium deoxycholate $(0 \cdot 2 \%)$ was successful at lower $\mathrm{pH}$ values, but the enzyme was inactivated.

Effect of $\mathrm{pH}$. The curve relating activity to $\mathrm{pH}$ (Fig. 3) shows an optimum at $\mathrm{pH} 5.4$ in the buffer used. Citric acid buffer was precluded because citrate inactivated the enzyme.

Substrate concentration. The effect of mannitol concentration on the rate of $\mathrm{O}_{2}$ uptake at $25^{\circ}$ was studied with a 'sodium acetate preparation' containing $0.017 \mathrm{M}-\mathrm{KH}_{2} \mathrm{PO}_{4}$ (pH 5). A plot of $S / v$ against $S$ by the method of Lineweaver \& Burk (1934) gave a linear graph from which $K_{m}$ was found to be $3.4 \times 10^{-2} \mathrm{M}$.

Effect of HCN. Oxygen uptake at $25^{\circ}$ and $\mathrm{pH} 5$ $\left(0.005 \mathrm{M}-\mathrm{KH}_{2} \mathrm{PO}_{4}\right)$ in the presence of mannitol $(150 \mu \mathrm{moles})$ was almost completely inhibited by $10^{-3} \mathrm{M}-\mathrm{HCN}$ in all preparations. Since anaerobic oxidation of mannitol with phenol blue or ferri-

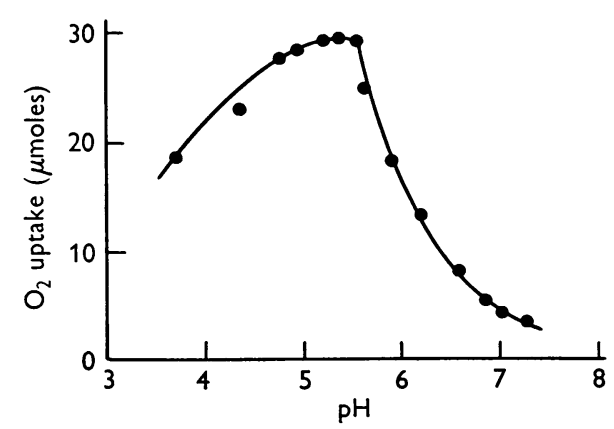

Fig. 3. Effect of $\mathrm{pH}$ on the activity of the 'acid' enzyme from A. suboxydans. Each Warburg flask contained $1.0 \mathrm{ml}$. of dialysed bacterial extract, $25 \mu$ moles of succinic acid- $\mathrm{Na}_{2} \mathrm{HPO}_{4}$ buffer and $150 \mu$ moles of mannitol (added from the side bulb after equilibration). Volume, $2.5 \mathrm{ml}$. Gas, air. Temp., 25 . Time, $1 \mathrm{hr}$. cyanide as oxidant was not inhibited, the locus of cyanide inhibition is likely to be the cytochrome carrier.

Anaerobic reduction of ferricyanide and dyes. On addition of mannitol (150 $\mu$ moles) the dialysed bacterial extract reduced ferricyanide and several redox indicators $\left(10^{-4} \mathrm{M}\right)$, e.g. phenol blue $(0 \cdot 3 \mathrm{~min}$.), phenolindo-2:6-dichlorophenol $(6 \mathrm{~min}$. $)$ and $o$ chlorophenolindo-2:6-dichlorophenol (8 min.). The approximate visual reduction times are given in brackets. Methylene blue, pyocyanine and brilliant cresyl blue were not reduced. Reduction of phenol blue or ferricyanide can be used under anaerobic conditions, or in the presence of cyanide, to determine the activity of the dehydrogenase by measuring decrease in optical density at 655 and $420 \mathrm{~m} \mu$. respectively (Fig. 4).

Cofactors. Although the addition of DPN does not increase the activity of the 'acid' enzyme (Table 1 ) it is possible that the coenzyme is firmly bound. A requirement for DPN or TPN was not induced by dialysis against water ( 6 days at $2^{\circ}$ ), $0.01 \mathrm{M}-\mathrm{Na}_{2} \mathrm{HPO}_{4}$ solution or $0.01 \mathrm{~m}$ acetate buffer, pH $4.5\left(48 \mathrm{hr}\right.$. at $\left.2^{\circ}\right)$, or by treatment with charcoal (Norit A, Pfanstiehl Chemical Co., U.S.A.) according to Velick, Hayes \& Harting (1953). The absorption

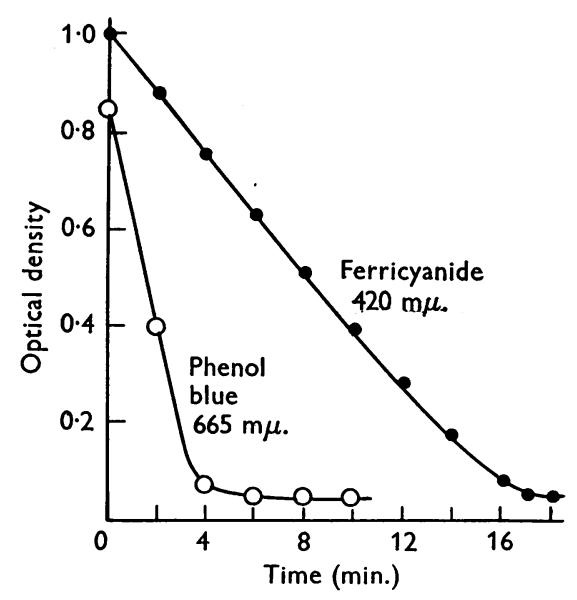

Fig. 4. Reduction of ferricyanide and phenol blue by the 'acid' enzyme of $A$. suboxydans. The cuvette containing potassium ferricyanide $(3.0 \mu \mathrm{moles})$ also contained $0.13 \mathrm{ml}$. of dialysed bacterial extract, $75 \mu$ moles of succinic acid- $\mathrm{Na}_{2} \mathrm{HPO}_{4}$ buffer, pH 5.2, $150 \mu$ moles of mannitol and $30 \mu$ moles of $\mathrm{KCN}$ (to prevent reoxidation of the carrier system); volume, 3.0 ml.; temp., $20^{\circ}$. The cuvette containing phenol blue $(1.0 \mu \mathrm{mole})$ also contained $0.2 \mathrm{ml}$. of bacterial extract (tenfold dilution of the original dialysed extract), $18 \mu$ moles of $\mathrm{KH}_{2} \mathrm{PO}_{4}$ (to give $\mathrm{pH}$ 5) and $150 \mu$ moles of mannitol; nitrogen was bubbled through the reaction mixture before the substrate was added; volume, $3.0 \mathrm{ml}$; temp., $20^{\circ}$. In the blank cuvettes water was substituted for the oxidant in both. There was no reduction in the absence of substrate. 
spectrum of enzyme preparations did not show increased absorption in the wavelength range $300-400 \mathrm{~m} \mu$. on addition of mannitol anaerobically. Although these observations do not exclude completely the participation of DPN in the dehydrogenation, they make it unlikely.

Attempts to separate the polyol dehydrogenase from the cytochrome and other constituents of the active particles by treatment with dilute alkali (pH 9.5) or with acetone or butanol (Morton, 1950) were unsuccessful. The activity was tested by following the reduction of phenol blue or ferricyanide spectrophotometrically.

When the bacterial extract $(50 \mathrm{ml}$.) was treated with sodium ethylenediaminetetraacetate (EDTA) $(50 \mu \mathrm{moles} / \mathrm{ml}$. of extract adjusted to $\mathrm{pH} 7 \cdot 1)$ and then dialysed to remove EDTA-metal complexes, the power to consume $\mathrm{O}_{2}$ in the presence of mannitol or sorbitol was lost. Oxygen consumption was restored by addition of $\mathrm{Ca}^{2+}$ and $\mathrm{Mg}^{2+}$ ions. Treatment with both EDTA and ammonium sulphate induced a further requirement. EDTA $(2.5 \mathrm{mM})$ was added to $50 \mathrm{ml}$. of fresh bacterial extract (pH 7.1) and the mixture dialysed against water at $2^{\circ}$ for 3 days. Then ammonium sulphate $(250 \mathrm{mg}$./ $\mathrm{ml}$.) was dissolved in the extract and the $\mathrm{pH}$ brought to $9 \cdot 0$ with $\mathrm{KOH}$. The precipitate was washed twice in ammonium sulphate solution $(250 \mathrm{mg} . / \mathrm{ml}$., $\mathrm{pH}$ adjusted to 9), suspended in water and dialysed overnight. The activity, partly restored by addition of calcium and magnesium, was enhanced by another factor (Table 3). This 'activator' was prepared by heating $\left(100^{\circ}\right.$ for $5 \mathrm{~min}$.) a portion of the same bacterial extract which had been treated with EDTA and dialysed, but not treated with ammonium

Table 3. Effect of calcium and magnesium ions and of an 'activator' on a preparation of the 'acid' enzyme previously treated with $E D T A$ and ammonium sulphate

Each Warburg flask contained $0.5 \mathrm{ml}$. of dialysed 'acid' enzyme preparation which had been treated with EDTA and ammonium sulphate (see text), $100 \mu$ moles of trissuccinic acid buffer, $\mathrm{pH} \mathrm{5.0}$, and $150 \mu$ moles of mannitol (added from the side bulb after equilibration). Volume, $2 \cdot 2 \mathrm{ml}$. Gas, air. Temp., $30^{\circ}$. Time, $1 \mathrm{hr}$. Inseal, $0 \cdot 2 \mathrm{ml}$. of $10 \%(w / v) \mathrm{KOH}$.

$\begin{array}{cccc}\begin{array}{c}\text { Additions } \\ \mathrm{Ca}^{2+}\end{array} & \begin{array}{c}\mathrm{Mg}^{2+} \\ (10 \mu \mathrm{moles})\end{array} & \begin{array}{c}\text { 'Activator'* } \\ (\mathbf{1 0} \mu \mathrm{m} \text { moles }) \\ \text { solution })\end{array} & \begin{array}{c}\mathrm{O}_{2} \text { uptake } \\ (\mu \mathrm{moles})\end{array} \\ - & - & - & 0 \cdot 1 \\ - & - & + & 0 \cdot 1 \\ + & + & - & 0.5 \\ + & - & + & \mathbf{3} \cdot \mathbf{4} \\ - & + & + & \mathbf{8 \cdot 3} \\ + & + & + & 11 \cdot 1\end{array}$

* See text for the preparation of the 'activator' solution. Note: the original extract $(0.5 \mathrm{ml}$.) consumed $20.5 \mu$ moles of $\mathrm{O}_{2}$ under the same conditions. sulphate. The denatured protein was removed by filtration. While investigating the oxidation of cyclitols in extracts of $A$. suboxydans Franzl \& Chargaff (1951) observed a similar effect due to a heat-stable factor present in the cells. The ions and the unidentified factor which restore the activity (measured manometrically or by anaerobic reduction of ferricyanide) may be involved in some part of the hydrogen- or electron-transporting mechanism other than the polyol dehydrogenase.

Cytochrome. The 'acid' enzyme preparations assume a pink tinge on addition of dithionite or an oxidizable polyol. The absorption spectrum of the oxidized pigment obtained by aeration shows a high maximum at $410 \mathrm{~m} \mu$., and the reduced form obtained by addition of $150 \mu$ moles of mannitol has the high maximum at $420 \mathrm{~m} \mu$. and low maxima at 520 and $550 \mathrm{~m} \mu$. An approximate difference spectrum plotted in a Beckman spectrophotometer with the oxidized form of the pigment in the reference cell showed maxima at 420,520 and $550 \mathrm{~m} \mu$. and minima at 405,450 and $525 \mathrm{~m} \mu$. These characteristics correspond fairly well to the accurate steady state values which Smith $(1954 a, b)$ has determined in cell suspensions of $A$. suboxydans. Smith (1954b) considers that the pigment of $A$. suboxydans is a unique bacterial cytochrome.

\section{Specificity of the 'acid' enzyme}

Table 4 shows the specificity of the enzyme towards polyols. Erythritol, ribitol, D-arabitol, mannitol, sorbitol and 6-deoxy-L-gulitol are oxidized rapidly; xylitol, allitol, D-talitol, volemitol, perseitol and $\beta$-sedoheptitol are oxidized slowly; L-arabitol, D-gulitol, dulcitol, L-gulo-D-gala-heptitol and the cyclitols are not oxidized. With the exception of the negative response to the cyclitols, these findings agree with the known behaviour of $A$. suboxydans in cultures. When oxidation occurred the product was a reducing substance giving a positive resorcinol test. Phenylosazones were prepared from a few of the products (Table 4). Although the 'acid' enzyme may exist in different states of aggregation in the preparations described, the specificity of all preparations was the same.

The unfractionated bacterial extract has the ability to oxidize glycerol (cf. Hauge, King \& Cheldelin, 1955), ethanol and n-, sec.- and isobutanol. There was no increase of $\mathrm{O}_{2}$ uptake in the presence of tert.-butanol, fructose, sorbose or succinate (Table 5).

\section{Properties of the 'alkaline' enzyme}

In some experiments the partially separated enzyme was used; in others the unfractionated bacterial extract was employed at $\mathrm{pH} 8$, which is outside the active range of the 'acid' enzyme. 
Table 4. Substrate specificity of the 'acid' enzyme of A. suboxydans

Each Warburg flask contained $1.0 \mathrm{ml}$. of enzyme (ammonium sulphate preparation), $100 \mu$ moles of tris-succinic acid

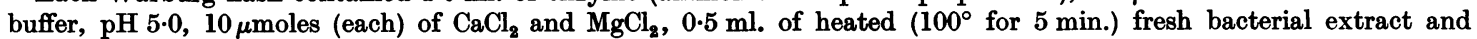
substrate. Volume, $2 \cdot 2 \mathrm{ml}$. Gas, air. Temp., $30^{\circ}$. Time, $1 \mathrm{hr}$. Inseal, $0 \cdot 2 \mathrm{ml}$. of $10 \%$ (w/v) KOH.

\begin{tabular}{|c|c|c|c|c|c|}
\hline Substrate & $\begin{array}{l}\text { Quantity } \\
\text { ( } \mu \text { moles) }\end{array}$ & $\begin{array}{c}\text { uptake } \\
\text { ( } \mu \text { moles) }\end{array}$ & $\begin{array}{c}\text { Reduction } \\
\text { test }\end{array}$ & $\begin{array}{l}\text { Resorcinol test } \\
\text { (Kulka, 1956) }\end{array}$ & Phenylosazone \\
\hline None & - & 0.0 & Negative & Negative & Negative \\
\hline Erythritol & 150 & $17 \cdot 3$ & Positive & Ketotetrose & - \\
\hline Ribitol & 150 & $6 \cdot 2$ & Positive & Ketopentose & - \\
\hline D-Arabitol & 150 & $15 \cdot 0$ & Positive & Ketopentose & 一 \\
\hline L-Arabitol & 150 & $0 \cdot 0$ & Negative & Negative & - \\
\hline Xylitol & 150 & $0 \cdot 4$ & Positive & Ketopentose & - \\
\hline Allitol & 40 & $1 \cdot 4$ & Positive & Ketohexose & Allosazone, m.p. $159-161^{\circ}$ \\
\hline D-Mannitol & 150 & $8 \cdot 5$ & Positive & Ketohexose & Glucosazone, m.p. $208^{\circ}$ (decomp.) \\
\hline D-Gulitol & 40 & $0 \cdot 0$ & Negative & Negative & 1 \\
\hline Sorbitol (L-gulitol) & 150 & $6 \cdot 4$ & Positive & Ketohexose & Idosazone, m.p. $160-164^{\circ}$ \\
\hline Dulcitol (galactitol) & 150 & $0 \cdot 0$ & Negative & Negative & - \\
\hline D-Talitol & 40 & $1 \cdot 8$ & Positive & Ketohexose & - \\
\hline 6-Deoxy-L-gulitol & 40 & $7 \cdot 4$ & Positive & Deoxyketohexose & 6-Deoxyidosazone, m.p. 168-172 \\
\hline $\begin{array}{l}\text { Perseitol (D-manno-D- } \\
\text { gala-heptitol) }\end{array}$ & 40 & $1 \cdot 9$ & Positive & Ketoheptose & $\begin{array}{l}\text { Perseulosazone, m.p. 194-197 } \\
\text { (decomp.) }\end{array}$ \\
\hline $\begin{array}{l}\text { Volemitol (D-manno-D- } \\
\text { talo-heptitol) }\end{array}$ & 40 & $1 \cdot 4$ & Positive & Ketoheptose & - \\
\hline $\begin{array}{l}\beta \text {-Sedoheptitol (L-gulo-D- } \\
\text { talo-heptitol) }\end{array}$ & 40 & $0 \cdot 4$ & Positive & Ketoheptose & 一 \\
\hline L-gulo-D-gala-Heptitol & 40 & $0 \cdot 0$ & Negative & Negative & - \\
\hline meso-Inositol & 150 & $0 \cdot 0$ & - & Negative & - \\
\hline$(+)$-Inositol & 30 & $0 \cdot 0$ & - & Negative & 一 \\
\hline ( -)-Inositol & $\mathbf{3 0}$ & $0 \cdot 0$ & - & Negative & - \\
\hline
\end{tabular}

Note: activity could not always be tested at high substrate concentrations because the supply of certain polyols was strictly limited. This applies also to Tables 7 and 9.

\section{Table 5. Oxidation of glycerol and butanol} by an extract of $\mathbf{A}$. suboxydans

Each Warburg flask contained $0.2 \mathrm{ml}$. of dialysed bacterial extract, $10 \mu$ moles of $0.1 \mathrm{~m}$ succinic acid- $\mathrm{Na}_{2} \mathrm{HPO}_{4}$ buffer, $\mathrm{pH} 5 \cdot 0$, and $150 \mu$ moles of substrate (added from the side bulb after equilibration). Volume, $1.0 \mathrm{ml}$. Gas, air. Temp., 25․ Time, $1 \mathrm{hr}$. Inseal, $0.2 \mathrm{ml}$. of $10 \%$ (w/v) KOH.

$\begin{array}{lc}\text { Substrate } & \begin{array}{c}\mathrm{O}_{2} \text { uptake } \\ (\mu \text { moles })\end{array} \\ \text { None } & 0 \cdot 0 \\ \text { Glycerol } & 7 \cdot 2 \\ \text { n-Butanol } & 5 \cdot 1 \\ \text { sec.-Butanol } & 10 \cdot 0 \\ \text { isoButanol } & 3 \cdot 0 \\ \text { tert.-Butanol } & 0 \cdot 0 \\ \text { Ethanol } & 4 \cdot 6\end{array}$

Table 6. Codehydrogenase specificity of the 'alkaline' enzyme

Each Warburg flask contained $0.5 \mathrm{ml}$. of dialysed bacterial extract, $15 \mu$ moles of sodium phosphate buffer, pH 8.0, $0.4 \mu \mathrm{mole}$ of coenzyme and $150 \mu \mathrm{moles}$ of substrate. Volume, $2 \cdot 7 \mathrm{ml}$. Gas, air. Temp., $25^{\circ}$. Time, $1 \mathrm{hr}$. Inseal, $0.2 \mathrm{ml}$. of $10 \%(\mathrm{w} / \mathrm{v}) \mathrm{KOH}$.

\begin{tabular}{ccc} 
& $\mathrm{O}_{2}$ uptake $(\mu$ moles $)$ \\
\cline { 2 - 3 } Coenzyme & Mannitol & Sorbitol \\
None & 0.4 & 0.9 \\
DPN & $5 \cdot 5$ & $6 \cdot 9$ \\
TPN & 0.8 & 1.3
\end{tabular}

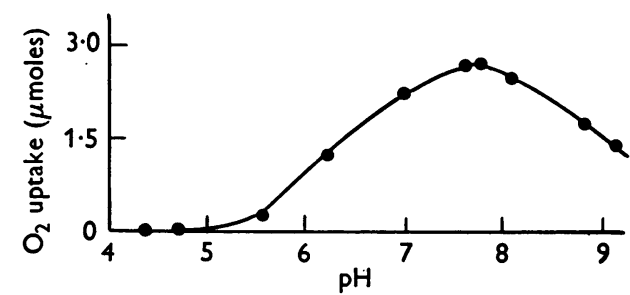

Fig. 5. Effect of $\mathrm{pH}$ on the activity of the 'alkaline' enzyme from $A$. suboxydans. Each Warburg flask contained $1.0 \mathrm{ml}$. of 'alkaline' enzyme solution (sodium acetate preparation), $20 \mu$ moles of succinic acid- $\mathrm{K}_{3} \mathrm{PO}_{4}$ buffer, $0.4 \mu$ mole of DPN, $1.6 \mu$ moles of methylene blue and $150 \mu$ moles of mannitol (added from the side bulb after equilibration). Volume, $2 \cdot 8 \mathrm{ml}$. Gas, air. Temp., $25^{\circ}$. Time, $1 \mathrm{hr}$.

Requirement for DPN and a hydrogen carrier. At pH 8 the dialysed unfractionated extract takes up $\mathrm{O}_{2}$ in the presence of mannitol or sorbitol if DPN is added (Table 1). When TPN is substituted for DPN the activity is slight (Table 6). After removal of the 'acid' enzyme and the associated carrier the 'alkaline' enzyme does not promote $\mathrm{O}_{2}$ consumption until methylene blue (optimum concentration $10^{-4} \mathrm{M}$ ) is added.

Effect of $\mathrm{pH}$. The $\mathrm{pH}$-activity curve shows an optimum at pH 7.8 in the buffer used (Fig. 5). 
Effect of HCN. The aerobic oxidation of polyols in the unfractionated extract at $\mathrm{pH} \mathbf{7 \cdot 8}$ is strongly inhibited by $\mathrm{HCN}\left(10^{-3} \mathrm{M}\right)$, but $\mathrm{O}_{2}$ uptake is not reduced by cyanide when the same oxidations are carried out with methylene blue as hydrogen carrier.

Substrate concentration. The rate of reaction catalysed by the 'alkaline' enzyme increases with substrate concentration to attain a maximum in the presence of approximately $0 \cdot 15 \mathrm{M}$ substrate, but the Lineweaver-Burk plot is not linear with mannitol or sorbitol.

\section{Substrate specificity of the 'alkaline' enzyme}

Table 7 shows the activity of the 'alkaline' enzyme towards polyols measured by the rate of reduction of DPN. Xylitol, mannitol, sorbitol, $\beta$-sedoheptitol and L-gulo-D-gala-heptitol are oxidized rapidly; D- and L-arabitol, D-talitol, L-iditol and volemitol are oxidized slowly. Erythritol, ribitol, D-gulitol, dulcitol, D-iditol, L-rhamnitol, perseitol and the cyclitols are not oxidized. The products of oxidation accumulating in aerobic experiments were reducing substances giving positive resorcinol tests. The ketose obtained from mannitol or sorbitol gave typical phenylglucosazone crystals, m.p. 202-206 ${ }^{\circ}$ (decomp.). A manometric experiment with a sodium acetate preparation of the enzyme $(2.0 \mathrm{ml}$. in $0.05 \mathrm{M}$ phosphate buffer, $\mathrm{pH} 7 \cdot 8)$ showed no $\mathrm{O}_{2}$ uptake in the presence of DPN $(0.4 \mu \mathrm{mole})$, methylene blue (1.6 $\mu$ moles) and allitol, glycerol, ethanol, fructose or sorbose ( $150 \mu$ moles $)$.

The product of sorbitol oxidation was analysed chromatographically. Each of two Warburg flasks contained in $2.9 \mathrm{ml}$. of solution $2.0 \mathrm{ml}$. of 'alkaline' enzyme (ammonium sulphate preparation), $300 \mu$ moles of sodium phosphate buffer, $\mathrm{pH} 7 \cdot 8,1 \cdot 0 \mu$ mole of DPN, 1.6 $\mu$ moles of methylene blue and $600 \mu$ moles of sorbitol. To one flask $60 \mu$ moles of sorbose was also added. Oxygen uptake at $30^{\circ}$ was $22 \mu \mathrm{moles} / 6 \mathrm{hr}$. in each flask. The contents of the flasks were passed successively through columns of Amberlite IR-120 ( $\mathrm{H}^{+}$form) and Amberlite IR-4 B $\left(\mathrm{HCO}_{3}{ }^{-}\right.$form) to remove protein, methylene blue and ions. The eluates were evaporated to dryness in vacuo at room temperature, the residues taken up in $0.2 \mathrm{ml}$. of water and subjected to descending paper chromatography at $25^{\circ}$ with a solvent composed of water-saturated phenol containing $0.04 \%$ of 8-hydroxyquinoline (Block, 1950). The chromatograms were sprayed with an orcinol reagent (Bevenue \& Williams, 1951), heated at $110^{\circ}$ for $10 \mathrm{~min}$. and the spots examined under ultraviolet light. The product from the flask which initially contained sorbitol gave a single spot with the same $R_{F}$ value $(0.52)$ as authentic fructose run concurrently, and the product from the flask which originally contained sorbitol and sorbose gave two well-separated spots with the same $R_{F}$ values as the reference spots due to authentic specimens of fructose $(0.52)$ and sorbose $(0.41)$ run concurrently.

Since sorbose is not oxidized, this experiment shows that the 'alkaline' enzyme converts sorbitol into fructose without forming a trace of sorbose detectable by the method used.

Reversibility. The oxidation of DPNH by Dxylulose, fructose, sorbose and perseulose is illustrated in Table 7 (cf. L-iditol dehydrogenase, McCorkindale \& Edson, 1954).

Possibility of the 'alkaline' enzyme being an artifact. Since the 'alkaline' enzyme possessed mannitoloxidizing power, it seemed possible that this enzyme might be a fragment which had been derived from the 'acid' enzyme during sonic treatment and

\section{Table 7. Substrate specificity of the 'alkaline' enzyme of A. suboxydans}

Each cuvette contained $\mathbf{0 . 5} \mathrm{ml}$. of 'alkaline' enzyme solution (ammonium sulphate preparation), $460 \mu$ moles of tris-succinic acid buffer, pH 7.8, $0.4 \mu$ mole of DPN or $0.01 \mu$ mole of DPNH and substrate as indicated. Volume, 3.0 ml. Temp., $20^{\circ}$.

\section{Substrate}

With DPN

None

Erythritol

Ribitol

D-Arabitol

L-Arabitol

Xylitol

Mannitol

D-Gulitol

Sorbitol (L-gulitol)

Dulcitol

D-Talitol

D-Iditol

L-Iditol

L-Rhamnitol

Volemitol

Perseitol

$\beta$-Sedoheptitol

L-gulo-D-gala-Heptitol

meso-Inositol

(+)-Inositol

( -)-Inositol

Quantity
( $\mu$ moles)

Optical density (340 $\mathrm{m} \mu$.)

Increase $/ 9 \mathrm{~min}$.

\section{With DPNH \\ None \\ D-Xylulose \\ D-Fructose \\ L-Sorbose \\ D-Tagatose \\ D-Mannoheptulose \\ D-Glucoheptulose \\ Perseulose}

180
120
120
120
10
10
25
10
100
200
10
12
100
20
30
35
30
100
10
10

$0 \cdot 000$

0.000

0.004

$0 \cdot 033$

0.034

$0 \cdot 303$

$0 \cdot 176$

0.001

$0 \cdot 184$

0.000

0.039

0.006

0.079

0.007

0.056

0.000

0.138

$0 \cdot 163$

0.001

0.003

0.005

Initial decrease/min.

0.003

$0 \cdot 170$

0.030

0.005

0.003

0.003

0.003

0.007

None

L-Sorbose

Perseulose

Decrease/15 min. 0.044 0.075 $0 \cdot 105$ 
had acquired a greater range of polyol-oxidizing power in the process. To test this possibility 'acid' enzyme that had been freed of 'alkaline' enzyme by sodium acetate treatment (see earlier) was subjected a second time to the action of the sonic disintegrator. The 'acid' enzyme preparation was also digested with various concentrations of trypsin at $25^{\circ}$ for $1 \mathrm{hr}$. The 'alkaline' enzyme activity was not produced in any of these experiments.

\section{'Alkaline' enzyme in the intact cells of Acetobacter suboxydans}

Although $A$. suboxydans is normally cultivated in acid media and does not grow at $\mathrm{pH} 7 \cdot 8$, washed cells suspended in $0.01 \mathrm{~m}$ phosphate buffer, $\mathrm{pH} \mathbf{7 . 5}$, consumed $\mathrm{O}_{2}$ rapidly at $25^{\circ}$ in the presence of sorbitol $(150 \mu \mathrm{moles})$. In the absence of substrate there was no $\mathrm{O}_{2}$ uptake. During the oxidation of sorbitol $38 \mu$ moles of $\mathrm{O}_{2}$ were consumed in $1 \mathrm{hr}$. and $11.7 \mu$ moles of fructose and $18.9 \mu$ moles of sorbose accumulated in the medium. The experiment appears to show that both the 'alkaline' and 'acid' enzyme are functioning in the cells, the action of the latter predominating, although the external $\mathrm{pH}$ is higher than the $\mathrm{pH}$ at which the extracted 'acid' enzyme ceases to oxidize sorbitol to sorbose. If these facts are to be explained in terms of enzymic properties, it would seem that the cells are able actively to maintain an internal $\mathrm{H}^{+}$ion concentration exceeding that of the external medium. Alternatively, they may transform fructose into sorbose.

\section{Polyol dehydrogenase activities of Candida utilis}

Mannitol and sorbitol, but not dulcitol (Table 8), are oxidized by a washed suspension of $C$. utilis, the cells of which were grown in the glucose-containing medium of Schultz \& Atkin (1947). The same effects are observed in suspensions of cells grown in a mannitol medium (see Methods). Ketoses do not accumulate in the suspending medium.

Dialysed cell-free extracts of $C$. utilis reduce DPN in the presence of polyols, the optimum $\mathrm{pH}$ for the reaction with mannitol being $9 \cdot 4$. The specificity of this polyol dehydrogenase preparation is illustrated in Table 9. Mannitol, sorbitol, xylitol and L-rhamnitol are oxidized rapidly; D-arabitol is oxidized slowly; erythritol, ribitol, L-arabitol, Dand L-iditol, dulcitol, meso-inositol and glycerol do not reduce DPN significantly at the concentrations used. Table 9 also contains a demonstration of reversibility: fructose oxidizes DPNH rapidly, sorbose slowly. Tagatose does not react.

Dialysed extracts of $C$. utilis do not consume $\mathrm{O}_{2}$ in the presence of polyols unless DPN and methylene blue are added to the reaction mixture. The products accumulating are reducing substances which give ketose colour reactions with resorcinol. The product of mannitol oxidation gave typical phenylglucosazone crystals, m.p. 208-209 (decomp.). The products of sorbitol oxidation were obtained from a Warburg flask in which $3 \mathrm{ml}$. of $C$. utilis extract was shaken at $30^{\circ}$ in air with $300 \mu$ moles of phosphate buffer, pH 7.8, $0.4 \mu$ mole of DPN, $1.6 \mu$ moles of methylene blue and $500 \mu$ moles of sorbitol. The $\mathrm{O}_{2}$ uptake was $9 \cdot 8 \mu$ moles $/ 12 \mathrm{hr}$. in the presence of sorbitol and negligible in its absence. At the end of the experiment the flask contents were deproteinized, concentrated by the method described for a similar experiment with the 'alkaline' enzyme of $A$. suboxydans (see above) and subjected to the same chromatographic analysis. The chromatogram showed two well-separated spots corresponding in colour and $R_{F}$ values to those obtained from a

\section{Table 8. Oxidation of hexitols by a washed suspension of $\mathrm{C}$. utilis}

Each Warburg flask contained $15 \mathrm{mg}$. of washed cells in $2.0 \mathrm{ml}$. of $0.9 \%$ (w/v) sodium chloride solution, $200 \mu$ moles of sodium phosphate buffer, pH 6.8, and substrate (added from the side bulb after equilibration). Volume, $2.4 \mathrm{ml}$. Gas, air. Temp., $30^{\circ}$. Time, $1.5 \mathrm{hr}$. Inseal, $0.2 \mathrm{ml}$. of $2 \mathrm{~N}-\mathrm{NaOH}$.

\begin{tabular}{lc}
\multicolumn{1}{c}{ Substrate } & $\mathrm{O}_{2}$ uptake \\
$(\mu$ moles $)$
\end{tabular}

Table 9. Reversible DPN-linked polyol dehydrogenase activity in extracts of C. utilis

Each cuvette contained $1.0 \mathrm{ml}$. of $C$. utilis extract, $300 \mu$ moles of glycine buffer, $\mathrm{pH} 9 \cdot 0$, either $0.4 \mu$ mole of DPN or $0.01 \mu$ mole of DPNH and substrate as indicated. Volume, 3.0 ml. Temp., $20^{\circ}$.

\begin{tabular}{|c|c|c|}
\hline Substrate & $\begin{array}{l}\text { Quantity } \\
\text { ( } \mu \text { moles) }\end{array}$ & $\begin{array}{c}\text { Change in } \\
\text { optical density } \\
(340 \mathrm{~m} \mu .) / 9 \text { min. }\end{array}$ \\
\hline \multicolumn{3}{|l|}{ With DPN } \\
\hline $\begin{array}{l}\text { None } \\
\text { Erythritol } \\
\text { Xylitol } \\
\text { Ribitol } \\
\text { D-Arabitol } \\
\text { L-Arabitol } \\
\text { Mannitol } \\
\text { Sorbitol } \\
\text { D-Iditol } \\
\text { L-Iditol } \\
\text { Dulcitol } \\
\text { L-Rhamnitol } \\
\text { Glycerol } \\
\text { meso-Inositol }\end{array}$ & $\begin{array}{r}- \\
200 \\
150 \\
300 \\
150 \\
300 \\
300 \\
300 \\
10 \\
55 \\
300 \\
300 \\
300 \\
300\end{array}$ & $\begin{array}{l}+0.009 \\
+0.010 \\
+0.140 \\
+0.013 \\
+0.095 \\
+0.008 \\
+0.172 \\
+0.150 \\
+0.009 \\
+0.008 \\
+0.013 \\
+0.155 \\
+0.008 \\
+0.020\end{array}$ \\
\hline \multicolumn{3}{|l|}{ With DPNH } \\
\hline $\begin{array}{l}\text { None } \\
\text { D-Fructose } \\
\text { L-Sorbose } \\
\text { D-Tagatose }\end{array}$ & $\begin{array}{l}\overline{300} \\
\mathbf{3 0 0} \\
\mathbf{3 0 0}\end{array}$ & $\begin{array}{l}-0.038 \\
-0.101 \\
-0.052 \\
-0.038\end{array}$ \\
\hline
\end{tabular}


reference mixture of fructose and sorbose in equal proportions. The relative intensities of the spots indicated that fructose was the main product of oxidation. The formation of fructose and sorbose from sorbitol in C. utilis extract at $\mathrm{pH} \mathbf{7 . 8}$ contrasts with the formation of fructose alone by the 'alkaline' enzyme of $A$. suboxydans under very similar conditions.

\section{DISCUSSION}

The first step in this study of the metabolism of polyhydric alcohols was the construction of a simple hypothesis to explain their occurrence in plants and their metabolism in animals and microorganisms (Edson, 1953). The hypothesis assumed that a general reaction, polyol $+\mathrm{DPN}^{+} \rightleftharpoons$ ketose + $\mathrm{DPNH}+\mathrm{H}^{+}$, was catalysed by three types of stereospecific polyol dehydrogenases (L-iditol, D-mannitol and galactitol dehydrogenases); and it was based largely on the properties of rat-liver polyol dehydrogenase (Blakley, 1951; McCorkindale \& Edson, 1954) and on the assumption that the behaviour of $A$. suboxydans in culture is due to the possession of D-mannitol dehydrogenase. Shaw $(1954,1956)$ has since demonstrated the existence of galactitol dehydrogenase in micro-organisms.

An examination of cell-free extracts from $A$. suboxydans has shown that the original hypothesis will not account for all the phenomena. The extracts contain at least two polyol dehydrogenase activities having different substrate specificities and $\mathrm{pH}$ optima, and apparently different cofactor requirements. The enzyme with a pH optimum about 5.5 is found in subcellular particles which can be sedimented by high-speed centrifuging. The particles also contain the cytochrome pigment peculiar to the organism. The methods used have failed to extract a soluble polyol dehydrogenase from the particles and to establish a requirement for DPN or TPN. The substrate specificity (Table 4) can be described by the Bertrand-Hudson rule (e.g. mannitol is oxidized to fructose and sorbitol to sorbose), and the enzyme is most active within the $\mathrm{pH}$ range that is optimum for the growth of the organism. It is proposed to call this enzyme the Bertrand-Hudson enzyme or cytochrome-linked D-mannitol dehydrogenase without prejudice to the possible intermediate links. Reversibility of its action has not been investigated. Although the polyol dehydrogenase activity is well defined, the complexity of the 'acid' enzyme preparation is revealed in its other enzymic properties (Table 5) such as the ability to oxidize glycerol (cf. King \& Cheldelin, 1954), ethanol and three butanol isomers.

The second polyol dehydrogenase ('alkaline' enzyme) is soluble, and has a pH optimum about $7 \cdot 8$, a requirement for DPN and a different sub- strate specificity (Table 7). Mannitol is oxidized to fructose according to the Bertrand-Hudson rule, whereas the oxidation of sorbitol to fructose follows the rule for L-iditol dehydrogenase; and the failure to oxidize dulcitol excludes an application of the rule for galactitol dehydrogenase (Shaw, 1956). There is no configuration common to all the substrates oxidized and absent from all those not oxidized. While it is possible that the 'alkaline' enzyme is a single polyol dehydrogenase, the substrate specificity of which cannot be described by a simple rule, it is also possible that the preparations contain more than one species of DPN-linked dehydrogenase. A plausible but not entirely satisfactory explanation is the combination of a stable DPN-linked mannitol dehydrogenase with an enzyme of the L-iditol dehydrogenase type.

The DPN-linked polyol dehydrogenase activity found in extracts of $C$. utilis (Table 9) resembles that of the 'alkaline' enzyme from $A$. suboxydans but is not identical. The important common features are the oxidation of mannitol to fructose, the vigorous attack on xylitol and the failure to oxidize dulcitol. Sorbitol oxidation reveals a difference, since the product formed by the $C$. utilis extract is a mixture of fructose and sorbose. This fact suggests that extracts of $C$. utilis contain more than one DPNlinked polyol dehydrogenase.

The DPN-linked polyol dehydrogenases occurring in $A$. suboxydans and $C$. utilis differ from other members of this class (L-iditol dehydrogenase, galactitol dehydrogenase) in possessing the ability to attack mannitol vigorously. Mannitol dehydrogenase requiring DPN was discovered by Müller (1937) in cell-free extracts of brewer's yeast and distinguished from alcohol dehydrogenase. Regardless of the number of DPN-linked polyol dehydrogenases which may be responsible for the observed oxidations (Tables 4, 7 and 9), it is proposed to call the soluble enzyme which attacks mannitol $D P N$ linked D-mannitol dehydrogenase. This enzymic activity is widely distributed (McCorkindale,1953; Edson, 1953; Shaw, 1956).

\section{SUMMARY}

1. Extracts of Acetobacter suboxydans contain a particulate dehydrogenase which catalyses the oxidation of polyols at $\mathrm{pH} 5$ without addition of diphosphopyridine nucleotide (DPN). The substrate specificity corresponds to the Bertrand-Hudson rule. The enzyme is associated with particles containing cytochrome and is named cytochromelinked D-mannitol dehydrogenase.

2. Extracts of $A$. suboxydans also contain soluble DPN-linked polyol dehydrogenase activity best developed about pH 8. The activity can be dissociated from the particles containing cytochrome. 
Although the substrate specificity does not conform to a simple rule, the enzyme oxidizes mannitol vigorously and is named DPN-linked D-mannitol dehydrogenase. Similar, but not identical activity occurs in extracts of $C$. utilis.

3. The problem of multiplicity of DPN-linked polyol dehydrogenases is discussed briefly.

We are much indebted to Dr N. K. Richtmyer, National Institutes of Health, Bethesda, U.S.A., and to Dr D. R. D. Shaw for generous gifts of rare polyols; and to the Virus Research Laboratory, Medical School, for the use of a Spinco Model L centrifuge.

\section{REFERENCES}

Bacon, J. S. D. \& Bell, D. J. (1948). Biochem. J. 42, 398. Bernhauer, K. (1938). Ergebn. Enzymforsch. 7, 246. Bernhauer, K. (1950). Ergebn. Enzymforsch. 11, 212. Bertrand, G. (1898). C.R. Acad. Sci., Paris, 126, 762. Bertrand, G. (1904). Ann. Chim. (Phys.), [8], 3, 181. Bevenue, A. \& Williams, K. T. (1951). Arch. Biochem. Biophys. 34, 225.

Blakley, R. L. (1951). Biochem. J. 49, 257.

Block, R. J. (1950). Analyt. Chem. 22, 1327.

Bollenback, G. N. \& Underkofler, L. A. (1950). J. Amer. chem. Soc. 72, 741.

Edson, N. L. (1953). Aust. N.Z. Ass. Adv. Sci., Rep. 29th Meeting, Sydney, 1952, 29, 281.

Franzl, R. E. \& Chargaff, E. (1951). Nature, Lond., 168, 955.

Fulmer, E. I. \& Underkofler, L. A. (1947). Iowa St. Coll. J. Sci. 21, 251.
Hann, R. M., Tilden, E. B. \& Hudson, C. S. (1938). J. Amer. chem. Soc. 60, 1201.

Hauge, J. G., King, T. E. \& Cheldelin, V. H. (1955). J. biol. Chem. 214, 1.

King, T. E. \& Cheldelin, V. H. (1954). Biochim. biophys. Acta, 14, 108.

Kluyver, A. J. \& de Leeuw, F. J. G. (1924). Tijdschr. vergelijk. Geneesk. 10, 170.

Kulka, R. G. (1956). Biochem. J. 63, 542.

Lineweaver, H. \& Burk, D. (1934). J. Amer. chem. Soc. 56, 658.

McCorkindale, J. (1953). Proc. Univ. Otago med. Sch. 31, 7. McCorkindale, J. \& Edson, N. L. (1954). Biochem. J. 57, 518.

Morton, R. K. (1950). Nature, Lond., 166, 1092.

Müller, D. (1937). Enzymologia, 3, 26.

Pratt, J. W., Richtmyer, N. K. \& Hudson, C. S. (1952). J. Amer. chem. Soc. 74, 2210.

Reichstein, T. (1934). Helv. chim. acta, 17, 996.

Richtmyer, N. K., Stewart, L. C. \& Hudson, C. S. (1950). $J$. Amer. chem. Soc. $72,4934$.

Schultz, A. S. \& Atkin, L. (1947). Arch. Biochem. 14, 369.

Shaw, D. R. D. (1954). Proc. Univ. Otago med. Sch. 32, 5.

Shaw, D. R. D. (1956). Biochem. J. 64, 394.

Smith, L. (1954a). Arch. Biochem. Biophys. 50, 299.

Smith, L. (1954b). Bact. Rev. 18, 106.

Steiger, M. \& Reichstein, T. (1935). Helv. chim. acta, 18, 790.

Stewart, L. C., Richtmyer, N. K. \& Hudson, C. S. (1949). $J$. Amer. chem. Soc. 71, 3532.

Stewart, L. C., Richtmyer, N. K. \& Hudson, C. S. (1952). J. Amer. chem. Soc. 74, 2206.

Totten, E. L. \& Lardy, H. A. (1949). J. Amer. chem. Soc. 71, 3076.

Velick, S. F., Hayes, J. E. \& Harting, J. (1953). J.biol. Chem. 203, 537.

\title{
Polyol Dehydrogenases
}

\section{GALACTITOL DEHYDROGENASE AND D-IDITOL DEHYDROGENASE}

\author{
By D. R. D. SHAW \\ Department of Biochemistry, Medical School, University of Otago, New Zealand
}

\section{(Received 22 February 1956)}

Although dulcitol occurs in many plants and is used as a substrate in fermentations which help to distinguish members of the family Enterobacteriaceae, very little is known about its metabolism. It appears that dulcitol is not metabolized by mammals (Embden \& Griesbach, 1914; Carr \& Krantz, 1934; Edson, 1936; Smith, Finkelstein \& Smith, 1940; Todd, 1954). On the other hand, most species of Salmonella can ferment dulcitol but the initial rate is slow in certain strains, suggesting that enzymic induction may precede dissimilation (Teague \& Morishimu, 1920; Kristensen, 1943). Apart from reports of 'acid' and 'gas' formation there seems to be no description of dulcitol catabolism in the Enterobacteriaceae.
Hermann \& Neuschul (1931) have reported that Acetobacter gluconicum converts dulcitol into a substance that reduces Fehling's solution but gives a negative Seliwanoff reaction. Without further evidence they considered the substance to be galactose. Some strains of staphylococci 'dehydrogenate' dulcitol as well as other polyols (Ö́mer, 1940), and the yeast Hansenula anomala takes up oxygen in the presence of dulcitol and other polyhydric alcohols (Usami, 1942). In the acetonebutanol fermentation of Clostridium acetobutylicum dulcitol gives a higher ratio of butyric acid to acetic acid than glucose (Simon, 1947). Shockley \& Randles (1954) found that non-proliferating cell suspensions of Lactobacillus sp. form acid from dulcitol when the 